\title{
Absolute dating of Copper and Early Bronze Age levels on the eponymous archaeological site Bubanj (South-Eastern Serbia)
}

\author{
Aleksandar Bulatović, Marc Vander Linden
}

\begin{abstract}
A. Bulatović (corresponding author):
Institute of Archaeology

Belgrade

Serbia

Email: abulatovic3@gmail.com

Marc Vander Linden:

Institute of Archaeology, University College London

31-34 Gordon Square

London WC1H OPY

United Kingdom
\end{abstract}

\begin{abstract}
This paper reports the first radiocarbon dates obtained for the Eneolithic / Bronze Age site of Bubanj, Serbia. Despite featuring prominently in the existing typo-chronological schemes for south-Eastern Europe, the history of research and recent large-scale destruction of the site had prevented so far the acquisition of samples from secure archaeological contexts. We fill this documentary gap by presenting ten new radiocarbon dates, covering the late 5th, 4th and 3rd millennium cal. BC. These dates are compared to the existing documentation from the literature, in order to assess the place of Bubanj within its wider archaeological context.
\end{abstract}

\section{Introduction}

The radiocarbon record for Later Prehistoric Europe is arguably one of the richest, if not the richest, across the world, both in terms of quantity of dates and density of geographical coverage. This being said, the state of affairs remains far from ideal as numerous documentary gaps persist, generally related to the history of local research and corresponding delays and logistical limits in adopting and using the radiocarbon technique. Without much surprise perhaps, one of these gaps is centered upon the central Balkans, corresponding to most of modern-day Serbia south of the Sava and Danube rivers. Whilst the record for the Mesolithic and Neolithic periods is good, 
thanks to the presence of famous sites which have attracted continuous scientific attention (e.g. the Danube Gorges and the site of Vinča; see recently Bonsall et al. 2015, Tasić et al. 2016), later periods are less well-covered. This situation is particularly unfortunate as this area lies at the crossroads of many natural communication routes connecting central Europe with the Balkan peninsula and, beyond, the Aegean and the Adriatic seas. The natural corridors include numerous large river valleys (Velika Morava, Južna Morava, Nišava rivers), and seem to have been preferentially settled during Later Prehistory.

The site of Bubanj, which is the focus of this paper, lies at the heart of one of these corridors, more precisely at the confluence of the Nišava and Južna Morava rivers, approximatively $5 \mathrm{~km}$ to the west of the modern city of Niš. The first excavations were conducted during the 1930s and provided important results quickly published by the Austrian Academy of Sciences in Vienna (Orsich de Slavetic 1940). This prehistoric site then covered an extensive surface estimated to c.3.5ha, stretching over three main areas (western, central and eastern), and appeared to have been almost continously occupied from the Neolithic to the Bronze Age (e.g. existence of stratigraphic profiles up to 3m high). Further excavations happened during the 1950s, mostly centered upon the central and western areas (Garašanin1958). Following this phase of fieldwork, sequence and material culture from Bubanj as eponymous site for several Eneolithic and Bronze age archaeological cultures (Garašanin 1958). It is noticeable that no samples were then taken for radiocarbon analysis, admittedly still in its early stages.

\section{Figure 1: location of the site of Bubanj, Serbia}

The first cultural group named after the site is the Bubanj-Hum I group, which corresponds to the Early Eneolithic in the local terminology. This group belongs to the larger Bubanj-SalcuţaKrivodol cultural complex (hereafter BSK), documented over much of the Balkans in western Bulgaria, south-western Romania, Serbia, as well as parts of Macedonia, Albania and Greece. While radiocarbon dates for this cultural complex are relatively numerous, there is a great imbalance in their geographical distribution, with so far only a single date available for the Central Balkans at the site of Bodnjik (western Serbia, Živanović 2013:54). As a result, precise chronological relationships between the regional variants of this complex remain poorly understood (e.g. lack of dates for Bubanj-Hum I in Serbia or Šuplevac-Bakarno Gumno in 
Macedonia; good chronology for both Salcuţa I-III in Romania and Krivodol I-II In Bulgaria: Lazarovici 2006, Boyadziev 1995). An overall attribution to the middle and/or second half of 5th millenium cal BC is widely accepted, on the basis of existing 14C dates and typological comparisons with older complexes (e.g. Kodžadermen-Gumelniţa-Karanovo VI in northern Bulgaria and south Romania: Boyadziev 1995; Nikolov and Petrova 2016; Gradešnica-SlatinoDikili Tash in southern Bulgaria and northern Greece: Boyadziev 1995; Roque et al. 2002).

For the Middle and Late Eneolithic, typological comparisons between Bubanj and other sites concern the Černavoda III, and Baden-Boleraz cultures (hereafter ČV III-B-B complex), Coţofeni-Kostolac and Bubanj-Hum II cultures (Jovanović 1976, Tasić 1979, Garašanin 1982: 153-155; Tasić 1995; Kapuran and Bulatović 2012). Typologically, the pottery assemblage from Bubanj belongs to the Černavoda III culture, but also presents numerous pottery typological traits echoing the central European Baden culture, especially its Boleraz horizon (Bulatović and Kapuran, forthcoming). Once more, the existing documentation is very unequal, with numerous dates for the Baden-Boleraz culture, mostly clustered in central Europe (Wild et al. 2001, Horvath 2008, Furholt 2008), whilst dates for the Černavoda III culture are so far only available for the site of Drama-Merdžumekja, in eastern Thrace (Bulgaria: Gleser 2011). The CoţofeniKostolac culture (hereafter K-K), attributed to the Late Eneolithic, is also sparsely dated, with only a single date for the central Balkans at the site of Belovode in Central Serbia, where a K-K layer was dated by chance in course of the analysis of Late Neolithic samples (Boric 2009: 196, Tab. 2). The Bubanj-Hum II group, although named after the site of Bubanj, will not be covered here as it was poorly represented in the recent excavations on which this paper is based (see below).

The situation is similar for the Early Bronze Age, a period for which the site of Bubanj is once more instrumental in the establishment of the relative chronology (cf. Bubanj-Hum III culture; herefater BH III). The Serbian archaeological literature, in the near absence of any radiocarbon dates (but see Bogdanović 1986; Gogaltan 1999, Krstić et al. 1986: 34), relies upon relative chronology and analogies with the material culture of neighbouring, absolutely dated cultures (Bulatović 2011), such as the Moriş (or Mokrin) culture to the north (O' Shea 1996) and Armenochori group to the south (Maniatis and Ziota 2011; Gori 2015), thus suggesting a date to the last quarter of the 3rd and the beginning of 2nd millenium BC. 
Here, we fill this damaging gap by presenting the first radiocarbon dates obtained for the site of Bubanj, covering both the Eneolithic and the Early Bronze Age. These new results, all obtained on samples from recently excavated secure archaeological contexts, are then compared to dates surveyed from the literature for each of the aforementioned archaeological complexes, in order to test the validity of the chronological estimates based upon traditional typological comparisons.

\section{Methods}

As previously mentioned, the site of Bubanj originally covered a total surface of c.3.5ha, distributed over a western, central and eastern area. Unfortunately, since the 1950s, the site has been subject to extensive destruction of various sorts. When a new archaeological field campaign was organised in 2008, only $200 \mathrm{~m}^{2}$ located in the eastern area were available for scientific investigations. Excavations were regularly conducted between 2008 and 2014 by the Archaeological Institute in Belgrade and National museum in Niš, in the course of which a broad range of samples were acquired, including bone samples for radiocarbon analysis reported here. Excavations were organised over a total surface of $150 \mathrm{~m}^{2}$, in a $1 \times 1 \mathrm{~m}$ square grid, coupled with artificial excavation spits of 3 to $5 \mathrm{~cm}$ deep. Archaeological structures were excavated as distinct coherent units.

Figure 2: plan of 2008-2014 excavations in Bubanj

Figure 3: 1-5, structure 69 (Bubanj-Hum I group); 6, structure 23 (ČV III-B-B complex); 7-10,

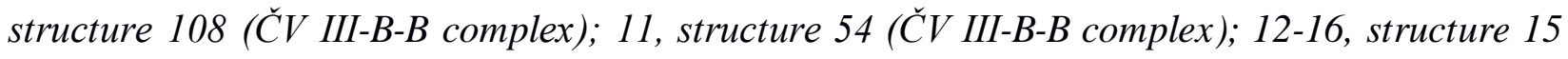
(K-K culture); 17-22, structure 3 (K-K culture); 23-28, structure 1 (Bubanj-Hum III culture).

The stratigraphy covers the Early Eneolithic (BSK), which immediately rests upon the soil substrate, the Middle (ČVIII B-B) and Late Eneolithic (K-K), each represented by two distinct horizons, and the Early Bronze Age (BH III). Younger deposits are absent because of extensive soil erosion and recent activity on the site, although finds from various periods are found at the surface and in the upper, heavily disturbed, metre of the statigraphy.

A total of ten samples, covering the entire stratigraphic sequence, were selected for radiocarbon dating. All samples were taken from secure stratigraphic contexts, and were closely associated 
with typologically well-defined pottery production. In order to minimise the risks of dating residual samples, animal bones were privileged as part of the sampling strategy, and were all identified by an experienced zooarchaeologist prior to submission for dating. Nine samples were submitted for counting to the SUERC Radiocarbon Dating Laboratory in Glasgow, where they were treated following the standard protocol described by Dunbar and colleagues (Dunbar et al. 2016). One supplementary sample was obtained from the Centre de Datation par le Radiocarbone, Lyon. Calibration and further Bayesian modelling (see below) were performed using Oxcal 4.2 (Bronk Ramsey 2009), using Intcal 13. All results are reported in Table 1.

Table 1: newly acquired 14C dates for the site of Bubanj

The oldest dates were provided by two animal bone samples recovered from the centre of an Eneolithic pit (structure 69), possibly of ritual function (Bulatovic 2015: 30, fig.3). Its opening is nearly circular (c. $1.7 \mathrm{~m}$ diameter), and its sides, deeply dug into the substrate (depth: $1.5 \mathrm{~m}$ ) were fire-baked. Its fill includes a mix of pottery fragments (Figure 3: 1-5), chipped stone tools, daub fragments, animal bones, ash and other finds (Bulatović 2015: Pl. II). The pottery typology points to an attribution to the BSK complex. The Middle Eneolithic is dated by four samples coming from the 17th artificial excavation spit, two pits and a scatter of pottery and animal bones. Pit 108 was dug from the lower horizon of this cultural layer, and probably corresponds to a refusal pit $(1,8 \times 1,2 \mathrm{~m}$, max depth $0,6 \mathrm{~m})$. It contained large amounts of pottery fragments (Figure 3: 7-10), animal bones, daub fragments, considerable quantity of burnt wood, a copper needle fragment, as well as other objects of baked earth and stone. The pottery belongs to the ČV III-B-B complex. Another dated pit (structure 54) has a nearly circular base, and was dug from the upper horizon of $\check{C} \mathrm{~V}$ III-B-B cultural layer (Tab. 1/4). It contained pottery fragments (Figure 3: 11) and animal bones. We also obtained a date from a bone sample coming from feature 23 (Tab. 1/6), a scatter of pottery and animal bones found in the lower horizon of ČV III-B-B complex (196.16-196.24 m asl). Once more, the pottery typology clearly points to the C̆V III-B-B complex (Figure 3: 6). The last sample from this horizon (Tab. 1/3) comes from the excavation layer and contained pottery characteristic for Č V III-B-B complex.

Two samples were obtained from sealed contexts for the $\mathrm{K}-\mathrm{K}$ horizon. A first sample was taken from the lower floor of a house (structure 15; Tab. 1/7), in direct association with K-K potsherds 
(Figure 3: 12-16). The second sample (Tab. 1/8), comes from the base of another house (structure 3/1), from the younger K-K horizon (Figure 3: 17-22), and is also directly associated with pottery characteristic for this culture. In the absence of secure stratigraphic contexts, it was decided not to take any sample from the layer above, in which material culture belonging to the Bubanj-Hum II group was found.

The Early Bronze Age (BH III group) is dated by finds coming from two secured stratigraphic contexts. The first sample (Table 1/10) comes from a deep pit, with a nearly circular base (diam.: c.1,4 m, depth: c. 1,6 m; structure 20). Although the upper part of the pit had been re-cut by a Medieval grave, it presented an interesting succession of fills, suggesting a refusal function. It contained pottery fragments, as well animal bones, daub fragments and other finds (bone awl, chipped stone tools). The dated sample is identifed as Equus species, although it is impossible to identify whether this corresponds to a wild or domesticated animal. The second sample comes from a shallow oval-shaped pit (structure 1) (Table 1/9), which contained numerous pottery fragments (Figure 3: 23-28), and some animal bones.

\section{Results and discussion}

In order to improve the precision of our results, we build a Bayesian model in OxCal 4.2. Such approach allows to constrain the probability distribution of radiocarbon dates through the inclusion of robust, independent chronological data, known as prior information (Bronk Ramsey 2009). In this case this prior information corresponds to the stratigraphic relationships between the samples. The resulting model includes as few assumptions as possible, with a single sequence of four bounded phases. The model presents an overall good agreement (Amodel: 102.9) (figure 4).

Figure 4: Bayesian modelling of the new radiocarbon dates for Bubanj

On the basis of the Bayesian modelling, the BSK horizon in Bubanj starts in 4618-4259 cal BC (95.4\% probability), possibly 4383-4273 cal BC (68.2\% probability) and ends in 4341-3739 cal BC (95.4\% probability), possibly 4331-4171 cal BC (68.2\% probability), thus pointing to a relatively short phase of use (duration: 0-68 years, 95.4\% probability; 0-30 years, 68.2\% probability). In order to compare this result with the overall development of the BSK complex, 
we compiled a dataset of all corresponding radiocarbon dates found in the literature (annex, table 2). This dataset only lists 38 dates for 13 sites, including Bubanj, showing the reduced size of the documentation, mostly coming from Bulgaria and Romania. This dataset was then used to build another Bayesian model, considering the BSK complex as a single bounded phase (Figure 5). Such approach provides quantitative estimates for the beginning and end of the modelled phase, which are more robust than mere visual inspections of the range of calibrated radiocarbon dates (Bayliss et al. 2007). This model (Amodel: 106.2) suggests that the BSK complex begins in 4573-4422 cal BC (95.4\% probability), possibly 4530-4465 cal BC (68.2\% probability), and ends in 3947-3806 cal BC (95.4\% probability), possibly 3932-3869 cal BC (68.2\% probability). Without much surprise given the small sample, the earliest expressions of the BSK complex are located in the well-dated areas, that is both western Bulgaria and Oltenia. Interestingly, the site of Bubanj lies slightly later in the sequence during the third quarter of the 5mill cal BC. Further precision is however hampered by the shape of the calibration curve for this period. The background of the emergence of the BSK complex has been discussed for a long time, especially regarding its relationship with the preceding Vinča culture. Recent Bayesian modelling of this culture, based upon a much larger dataset, suggests that its later ceramic phase Vinča D began in 4870-4725 cal BC (95.4\% probability), possibly in 4810-4740 cal BC (68.2\% probability), and ended in 4515-4360 cal BC (95\% probability), possibly in 4490-4415 cal BC (68.2\% probability) (Whittle et al. 2016). The comparison between both models suggests a one to two centuries overlap between both ceramic styles.

Figure 5: Bayesian modelling of radiocarbon dates for the BSK complex (dates listed in table 2)

The second cultural phase represented in the new Bubanj excavations corresponds to the ČV IIIB-B complex. Our Bayesian model suggests that this horizon began in 3717-3334 cal BC (91.3\% probability), possibly 3434-3345 cal BC (62.8\% probability) and ended in 3361-3106 cal BC (95.4\% probability), possibly 3359-3258 cal BC (62.7\% probability), with a duration spanning one to three centuries (duration: 0-275 years, 95.4\% probability; 0-79 years, $63.7 \%$ probability). There is also a noticeable gap between this and the preceding $\mathrm{BH}$ I horizon, estimated to have lasted between two to more than nine centuries (Interval BSK-ČV III: 223-983 years, 92.4\% probability; 673-953 years, $68.2 \%$ probability). This situation is widely encountered across the 
territory of modern-day Serbia, where the archaeological record for the early $4^{\text {th }}$ mill cal BC is scanty, especially when compared to neighboring countries. It is impossible to assess whether this gap is a by-product of modern research or reflects a past reality, though the last hypothesis should not be discarded as several recent studies in other European regions point to the existence of fluctuations in demographic regimes and settlement patterns (see review in Shennan 2012).

The nature of the Baden culture, and its relationships with the Cernavoda III culture have long been discussed, and chronology has prominently featured in this debate. The Baden culture is generally dated between 3650 and 2800 cal BC (Wild et al. 2001, Horváth et al. 2008, Furholt 2008). Furholt points to the existence of an early phase, characterised by coarse wares, dated to 3650-3350 cal BC, immediately followed by the Boleraz phase, dated to 3520-3350 cal BC, which is characerised by fine wares and a process of spatial expansion (Furholt 2008). Links between this Boleraz phase and the Černavoda III culture have been suggested on typological ground (see below). Wild and colleagues (2001) rejected this hypothesis by showing, on basis of few dates, the contemporaneity of the Baden culture with the Černavoda I culture, which supposedly precedes the Černavoda III one (Roman 1999). Their argument is however flawed by the fact that the precise contexts from which these dates were taken are contested (Nikolova 1999: 89-09).

The overall chronological brackets of the Baden culture are confirmed by our own analysis of the literature, which included 113 dates distributed over 40 sites (annex, table 3). A simple Bayesian modelling of this dataset (figure 6), as a single bounded phase, indeed confirms that the whole Baden culture began in 3667-3578 cal BC (95.4\%), possibly 3652-3609 cal BC (68.2\% probability), and ended in 2886-2824 cal BC (95.4\% probability), possibly 2876-2846 cal BC (68.2\% probability). We then compared these results with a similar Bayesian modelling of the few existing dates for the Černavoda III culture (figure 6), which so far only consist of five dates from the sites of Drama-Merdžumekja (Bulgaria: Gleser 2011), and the four dates for Bubanj reported here (annex, table 4). Given the scarcity of the evidence, we adopted a conservative approach by inserting all dates, although the oldest one (Erl-14441, 4751 \pm 57 BP) presents a poor overall agreement $(A=55.6)$. The model suggests that the Černavoda III culture began in 35513353 cal BC (95.4\% probability), possibly in 3416-3359 cal BC (68.2\% probability), and ended in 3369-3166 cal BC (95.4\% probability), possibly in 3358-3317 cal BC (68.2\% probability). This confirms that the Černavoda III is culture starts later than the beginning of the Baden 
culture, but is strictly contemporaneous with the Boleraz phase. Despite the controversy, such result should not be a surprise, given that numerous sites in the central Balkans present traits from both complexes in close association (e.g. lids of Bratislava type, bowls with funnel shaped neck channeled on the interior, plastic appliques on rim and other, Fischbute, ball shaped smaller pots decorated with vertical channels, bowls of everted $\mathrm{S}$ profile with accentuated shoulder ornamented with two horizontal rows of pitted dots and other: Bulatović and Kapuran, forthcoming). These new dates thus suggest that the process of spatial expansion associated with the Boleraz phase (Furholt 2008) had wider repercussions, exemplified by the presence of the aforementioned typological traits in the ČV III culture in the central Balkans.

Figure 6: Up. Bayesian modelling of radiocarbon dates for the Baden culture (dates listed in table 3). Down: Bayesian modelling of dates for the Črnavoda III culture (dates listed in table 4)

The third cultural horizon represented in the new Bubanj excavation is associated with the K-K culture. According to the Bayesian model, this horizon began in 3335-3018 cal BC (95.4\% probability), possibly 3108-3039 cal. BC (66.2\% probability) and ended in 3108-2326 (95.4\% probability), possibly 3083-2821 cal BC (68.4\% probability) (duration: 0-225 years, 95.4\% probability; 0-94 years, $68.2 \%$ probability). This third horizon is separated from the previous ČVIII horizon by a compact grey layer, interpreted as a surface leveled on purpose by the settlers associated with the $\mathrm{K}-\mathrm{K}$ horizon. This reading is partly confirmed by the rapid succession between both phases, estimated to $0-275$ years (95.4\% probability), possibly $0-154$ years (68.2\% probability). Based upon already published dates (annex table 5; figure 7), we estimate the start of the K-K culture to 3352-3037 cal BC (95.4\% probability), possibly 3205-3058 cal BC (68.2\% probability), and its end to $2875-2667$ cal BC (95.4\% probability), possibly 2862-2771 cal BC (68.2\% probability), thus confirming previous estimates (Nikolić 2000: 78). The dates from Bubanj nearly cover the entire sequence of this culture, and appear to be roughly contemporaneous with both Kostolac (sites of Vučedol, Pivnica and Gomolava: Benko et al. 1989; Bojadžiev 1992; Waterbolk 1988), and Coţofeni facies (Bojadžiev 1992, Bojadžiev 1998: 357). 
Figure 7: Bayesian modelling of radiocarbon dates for the Kotofeni-Kosolac complex (dates listed in table 5)

Given the aforementioned poor preservation of the upper part of the stratigraphic profile, we were only able to obtain dates from secure contexts for the BH III layer, corresponding to the Early Bronze Age in the local terminology. The extensive damage occasioned to the stratigraphy is confirmed by the chronological gap between this horizon and the preceding one, estimated to 102-1080 years (95.4\%), possibly 575-1036 years (68.4\%). The BH III horizon in Bubanj began in 2624-1946 cal BC (95.4\% probability), possibly 2191-1976 cal BC (68.2\% probability), and ended by 2121-1652 cal BC (95.4\% probability), possibly 2030-1869 cal BC (68.4\% probability), and thus lasted a century at most (duration: 0-128 years, 95.4\% probability; 0-47 years: 68.4\% probability). These estimates are older than dates from the oldest horizon at the site of Ljuljaci, attributed to the proto-Vatin (Bogdanović 1986), or Bubanj-Hum IV-Ljuljaci group (Bulatović and Stankovski 2012: 343-347), which is considered as the beginning of the Middle Bronze Age in the Central Balkans. Dates for BH III horizon at Bubanj are broadly contemporaneous with the Moriş (or Mokrin) culture from the Hungarian plain (Table 6; O' Shea 1996), and the Armenochori group in northern Greece (Table 6; Maniatis and Ziota 2011). These three cultural groups indeed share several stylistical and typological pottery traits (Garašanin 1982; Bulatović, Stankovski 2012).

\section{Conclusion}

These radiocarbon dates for the site of Bubanj, one of the key prehistoric locations in southeastern Europe, provide a breakthrough in the chronology of Eneolithic and Bronze Age periods in the Central Balkans as these correspond to the first absolute dates for certain prehistoric periods over this area.

The absolute dates for the BSK, K-K and B-H III horizons all confirm the previous chronological estimates based on typological comparisons, and reinforce the importance of the site of Bubanj in the typological and cultural sequences of the Eneolithic and Early Bronze Age in the Balkans. The dates for the ČV III horizon are very significant. Not only do they provide the first dates for this culture in the central Balkans (and only the second for this entire culture), but they also indicate to a strict contemporaneity with the Boleraz phase of the Baden culture, thus pointing to 
the complex cultural interactions happening across central Europe during the late $4^{\text {th }}$ millennium cal BC. Conversely, they cast doubt on the validity of the $\check{C} \mathrm{~V}$ I- $\breve{C V}$ III sequence, although in this case inadequacies in the original dates for the $\check{C} \mathrm{~V}$ I culture cannot be ruled out.

All in all, this contribution calls for further sampling and dating of Eneolithic and Bronze Age sites across the Balkans. As we have shown here, significant results can be obtained through careful sampling combining robust stratigraphic and typological information, and a relatively limited number of dates, which makes the approach viable, especially in research areas where funding is often a limited resource.

\section{Acknowledgments}

The majority of 14C dates and Vander Linden's contributions are an output from the European Research Council project EUROFARM, funded under the European Union's Seventh Framework Programme (FP/2007-2013; ERC Grant Agreement no. 313716). Date of sample from structure 20 has been supported by a European Research Council Advanced Investigator Grant (295412), The Times of Their Lives (www.totl.eu), led by Alasdair Whittle and Alex Bayliss

\section{References}

Bayliss A, Bronk Ramsey C, van der Plicht J, Whittle A. 2007. Bradshaw and Bayes: towards a timetable for the Neolithic. Cambridge Archaeological Journal 17 (S1): 1-28.

Benkö L, Horvath L, Horvatinčić N, Obelić B. 1989. Radiocarbon and Thermoluminescence Dating of prehistoric sites in Hungary and Yugoslavia, Radiocarbon 31(3): 992-1002.

Bogdanović M. 1986. Љуљаци, насеље протоватинске и ватинске културе Крагујевац.

Bojadziev J. 1992. Probleme der Radiokohlenstoffdatierung der Kulturen des Spätäneolitikums und der Frühbronzezeit. Studia Praehistorica 11-12: 389-406.

Boyadziev Y. 1995. Chronology of Prehistoric Cultures in Bulgaria. In: Bailey DW, Panayotov I, editors. Prehistoric Bulgaria. p. 149-91.

Bojadžiev J. 1998. Radiocarbon Dating From Southeastern Europe. In: Stefanovich M, Todorova H, Hauptmann H, editors. James Harvey Gaul, in memoriam: 349-70. Sofia.

Bonsall C, Macklin MG, Boroneanţ A, Pickard C, Bartosiewicz L, Cook GT, Higham TFG. 2015. Holocene climate change and prehistoric settlement in the lower Danube valley. Quaternary International 378: 14-21.

Borić D. 2009. Absolute Dating of Metallurgical Innovations in the Vinča Culture of the Balkans. In: Keinlin TL, Roberts BW, editors. Metals and Societes, Studies in honour of Barbara S. Ottaway: 191-245.

Bronk Ramsey C. 2009. Bayesian analysis of radiocarbon dates. Radiocarbon 51(1): 337-360.

Bulatović A. 2011. Relations between Cultural Groups in the Early Bronze Age in Southeastern Serbia, Western Bulgaria and North-eastern Macedonia. Archaeologica Bulgarica XV(2): 81-94. Bulatović A, Stankovski J. 2012. Бронзано доба у басену Јужне Мораве и у долини Пчине, Београд-Куманово.

Bulatović A. 2015. Феномен праисторијских ритуалних јама, неколико примера са централног Балкана (The Phenomenon of prehistoric ritual pits, several examples from the Central Balkans - resume), Старинар н.c. LXV: 7-35. In Serbian. 
Bulatović A, Kapuran A. forthcoming, Cristian I. P. (ed.), The Carpathian Basin and the Northern Balkans between 3500 and 2500 BC: Common Aspects and Regional Differences /Annales Universitatis Apulensis: Series Historica, 20/II (2016).

Dunbar E, Cook GT, Naysmith P, Tripney BG, Xu S. 2016. AMS ${ }^{14} \mathrm{C}$ dating at the Scottish Universities Environmental Research Centre (SUERC) radiocarbon dating laboratory. Radiocarbon 58(1): 9-23.

Durman A, Obelić B. 1989. Radiocarbon dating of Vučedol cultural complex. Radiocarbon 31(3): 1003-9.

Forenbaher S. 1993. Radiocarbon Dates and Absolute Chronology of the Central European Early Bronze Age, Antiquiy 67: 218-56.

Furholt M. 2008. Pottery, culture, people? The European Baden material re-examined. Antiquity 82: 617-628.

Garašanin M. 1958. Kontrollgrabung in Bubanj bei Niš, Praehistorische Zeitschrift XXXVI: 22344.

Garašanin M. 1982, The Eneolithic period in the Central Balkan Area. In: Boardman J, Edwards IES, Hammond NGL, Sollberger E. editors. The Cambridge Ancient History, vol. III. Cambridge: Cambridge University Press. p. 136-62.

Girić M. 1987. Die Erforschung der Äneolitishen Hügelgräber in nördlichen Banat, Simposium, Donji Milanovac, Serbia 1985, 71-6.

Gleser R, Thomas M, 2012, Merdžumekja-Südosthang, Späte Kepferzeit und früheste Bronzezeit: Ergebnisse siedlungsarchäologischer Forschungen Bonn: Habelt-Verlag.

Gogâltan F. 1999. Bronzul timpuriu și mijlociu în Banatul românesc pe cursul inferior al Mureșului. I, Cronologia și descoperirile de metal, Ed. Orizonturi Universitare, Timişoara.

Gori M. 2015. Along the Rivers and Through the Mountains. A reviewed chrono-cultural framework for the south-western Balkans during the late 3rd and early 2nd millennium BCE, Universitätsforschungen zur Prähistorischen Archäologie, Bonn: Habelt.

Horváth T, Svingor E, Molnar M. 2008. New radiocarbon dates for the Baden Culture, Radiocarbon 50(3): 447-58.

Jovanović B. 1976. Obredi sahranjivanja u kostolačkoj grupi, Godišnjak Centra za balkanološka ispitivanja ANUBIH, knj. XIII: 131-42. In Serbian.

Kalafatić H. 2006. A Vinkovci Culture Urn Grave from the site at 40 Duga Ulica in Vinkovci, Prilozi Instituta za arheologiju u Zagrebu, 23/2006: 17-28.

Kapuran A, Bulatović A. 2012, Културна група Коцофени-Костолац на територији источне Србије, Старинар н.с. LXII: 63-94.

Krstić D, Bankoff A, Vukmanović M, Winter F. 1986. Праисторијски локалитет Новачка ћуприја, Зборник Народног музеја и Београду 12(1): 17-63.

Lazarovici CM. 2006. Absolute Chronology of the Late Vinča Culture in Romania and its role in the Development of the Early Copper Age. In: Tasić N, Grozdanov C. editors. Hommage to Milutin Garašanin: 277-93.

Maniatis Y, Ziota C. 2011. Systematic ${ }^{14} \mathrm{C}$ dating of a unique Early and Middle Bronze Age Cemetery at Xeropigado Koiladas, West Macedonia, Greece, Radiocarbon 53(3): 461-78.

Nikolić D. 2000, Kostolačka kultura na teritoriji Srbije. Beograd: Filozofski fakultet u Beogradu, Centar za arheološka istraživanja.

Nikolov V, Petrova V. 2016. Tell Karanovo: The hiatus between the Late Copper and the Early Bronze Age. In: Tsirtsoni Z. editor. The human face of Radiocarbon, Reassessing Chronology in Prehistoric Greece and Bulgaria, 5000-3000 cal BC: 127-40. 
Nikolova L. 1999. The Balkans in Later Prehistory. Periodization, chronology and cultural development in the Final Copper and early Bronze Age (fourth and third millennia BC). Oxford: British Archaeological Reports International Series 791.

Orssich de Slavetich A. 1940, Bubanj, eine vorgeschichtliche Ansiedlung bei Niš, Mitteilungen der Prähistorischen Kommission der Akademie der Wissenschaften IV. Band, Nr. 1-2, Wien: 146.

O' Shea JM. 1996, Villagers of the Maros: A Portrait of an Early Bronze Age Society. Michigan: University of Michigan Press.

Reimer PJ, Bard E, Bayliss A, Beck JW, Blackwell PG, Bronk Ramsey C, Buck C.E., Cheng H., Edwards RL, Friedrich M, Grootes PM, Guilderson TP, Haflidason H, Hajdas I, Hatté C, Heaton TJ, Hoffmann DL, Hogg AG, Hughen KA, Kaiser KF, Kromer B, Manning SW, Niu M, Reimer RW, Richards DA, Scott EM, Southon JR, Staff RA, Turney CSM, van der Plicht J (2013) IntCal13 and Marine13 radiocarbon age calibration curves 0-50,000 Years cal BP. Radiocarbon 55(4): 1869-1887.

Roque C, Guibert E, Vartanian E, Bechtel F, Treuil R, Darcque P, Koukuli-Chryssanthaki H, Malamidou D. 2002. The Chronology of the Neolithic sequence at Dikili Tash, Macedonia, Greece: TL Dating of domestic ovens. Archaeometry 44 (4): 613-33.

Shennan SJ 2012. Demographic Continuities and Discontinuities in Neolithic Europe: Evidence, Methods, Implications. Journal of Archaeological Method and Theory 20 (2): 300-311.

Sorin O. M. 2003. The Cernavoda III-Boleraz Phenomenon: after 30 years. European

Archaeology/online: 1-39. Accessed November 29, 2016.

http://www.archaeology.ro./pagini/preistorie.html.

Tasić N. 1979. Coțofeni kultura. In: A. Benac (ed.), Praistorija jugoslavenskih zemalja III, ANUBiH, Centar za balkanološka ispitivanja, Sarajevo: 115-28.

Tasić N. 1995 Eneolithic cultures of Central and West Balkans, Beograd.

Tasić N, MarićM, Filipović D, Penezić K, Dunbar E, Reimer P, Barclay A, Bayliss A, Gaydarska B, Whittle A. 2016. Interwoven strands for refining the chronology of the Neolithic tell of VinčaBelo Brdo, Serbia. Radiocarbon 58(4): 795-831.

Waterbolk TH. 1988. ${ }^{14}$ C Datirungen von Gomolava, Simposium in Ruma, Serbia 1986, Novi Sad: $117-21$.

Whittle A, Bayliss A, Barclay A, Gaydarska B, Bánffy E, Borić D, Draşovean F, Jakucs J, Marić M, Orton D, Pantović I, Schier W, Tasić, Vander Linden M. 2016. A Vinča potscape: formal chronologcal models for the use and development of Vinča ceramics in south-east Europe. Documenta Praehistorica 43: 1-60.

Wild EM, Stadler P, Bondár M, Draxler S, Friesinger H, Kutschera W, Priller A, Rom W, Ruttkay E, Steier P. 2001. New Chronological frame for the young Neolithic Baden culture in central Europe (4th Millennium BC), Radiocarbon 43(2B): 1057-64.

Živanović Z. 2013. Енеолитска градина Бодюик, Завичајни музеј, Коцељева. 